\title{
State of Discrimination Report
}

Bhuvana Anand ${ }^{1}$ and Sarvnipun Kaur ${ }^{1}$

${ }^{1}$ Affiliation not available

March 8, 2022

\section{Hosted file}

Typeset report _ State of Discrimination Report _ March 2020.pdf available at https: //authorea.com/users/462272/articles/558891-state-of-discrimination-report 